\title{
Pengaruh Pendekatan Saintifik terhadap Kemampuan Bahasa Ekspresif Anak Kelompok B
}

\author{
Fianti Sari ${ }^{1}$, I Made Suardana ${ }^{2}$, M. Zainuddin ${ }^{2}$ \\ ${ }^{1}$ Pendidikan Anak Usia Dini-Universitas Negeri Malang \\ ${ }^{2}$ KSDP-Universitas Negeri Malang
}

\begin{tabular}{l}
\hline INFO ARTIKEL \\
\hline Riwayat Artikel: \\
Diterima: $16-09-2019$ \\
Disetujui: $17-04-2020$ \\
\hline
\end{tabular}

\section{Kata kunci:}

scientific approach; expressive language; pendekatan saintifik; bahasa ekspresif

\author{
AlamatKorespondensi: \\ Fianti Sari \\ Pendidikan Anak Usia Dini \\ Universitas Negeri Malang \\ Jalan Semarang 5 Malang \\ E-mail: fiantisari86@gmail.com
}

\begin{abstract}
ABSTRAK
Abstract: The purpose of this research is to study the application of scientific evaluation in the development of expressive language of group B children in TK PGRI 1 Wagir. The research used was a quantitative experiment. The research subjects consisted of 2 groups: the experimental and control groups each of 15 students. Data collection by the method of collection, interview and documentation. Data analysis using t test, the Paired Samples Test. Based on the analysis of the Paired Samples Test, the $t$ value was 28.375 in the experimental group. Significant value of 0,000 , which means less than 0.05 . These results prove that scientific support is effective for the development of expressive language aspects of children B in TK PGRI 1 Wagir.

Abstrak: Tujuan dari penelitian ini adalah untuk mengetahui pengaruh penerapan pendekatan saintifik dalam pengembangan aspek bahasa ekspresif anak kelompok B di TK PGRI 1 Wagir. Pendekatan penelitian yang digunakan adalah kuantitatif Quasy Eksperimen. Subjek penelitian terdiri dari dua kelompok, yaitu kelompok eksperimen dan kontrol masing-masing 15 anak didik. Pengumpulan data dengan metode observasi, wawancara dan dokumentasi. Analisis data menggunakan uji t yaitu Paired Samples Test. Berdasarkan analisis Paired Samples Test menunjukkan nilai t hitung sebesar 28.375 pada kelompok eksperimen. Nilai signifikasi 0.000 yang artinya lebih kecil dari 0.05. Hasil ini membuktikan bahwa pendekatan saintifik efektif untuk pengembangan aspek bahasa ekspresif anak kelompok B di TK PGRI 1 Wagir.
\end{abstract}

Anak mempunyai kemampuan pada aspek bahasa sejak usia dini. Kemampuan ini harus distimulus dengan baik melalui komunikasi dan interaksi antar manusia. Sebagaimana ungkapan Vygotsky (dalam Dhieni, 2013) bahasa mempunyai nilai sosial untuk berinteraksi antar manusia. Untuk mengekspresikan dan menyampaikan pendapatnya anak membutuhkan kemampuan berbahasa ekspresif. Oleh karena itu, keterlibatan guru dan lingkungan sekitar diharapkan dalam memfasilitasi kebutuhan anak dalam menyampaikan perasaannya melalui kata-kata, berbicara dengan orang lain dan mengekspresikan pikirannya. Kemampuan berkomunikasi tersebut perlu didukung metode yang tepat dan cermat (Inten, 2017). Hal itu didukung oleh pendapat Tarigan 2008 (dalam Madyawati, 2016) yaitu kecepatan perkembangan bahasa ekspresif anak sangat mengagumkan, meskipun kosa katanya masih terbatas. Kemampuan tersebut akan terus berkembang seiring dengan bertambahnya usia anak.

Perkembangan bahasa adalah salah satu aspek perkembangan yang termuat dalam kurikulum PAUD tahun 2013. Dalam STTPA kurikulum PAUD tahun 2013 dibahas mengenai kompetensi dasar dan muatan pembelajaran bahasa untuk anak usia dini. Menurut Rosalina (2011) aspek linguistic atau bahasa sangat penting dikembangkan sejak usia dini dengan rangkaian kegiatan bermain. Dengan bermain, anak dapat berkomunikasi untuk pengembangan bahasa ekspresif (Jafar \& Satriana, 2018). Kurikulum PAUD 2013 menjelaskan bahasa anak terdiri dari bahasa reseptif dan ekspresif. Bahasa reseptif adalah kemampuan anak untuk menyimak dan mendengar ucapan maupun perkataan orang lain, sedangkan berbahasa ekspresif adalah kemampuan atau cara anak untuk mengungkapkan perkataan, ucapan maupun gagasan. Santrock (2011) menjelaskan bahasa pada anak terdiri dari rangkaian kata-kata yang bervariasi sehingga dapat dimengerti oleh orang yang mendengarkannya. Pada anak usia 4-6 tahun bahasa digunakan untuk mengungkapkan harapan dan keinginannya.

Tujuan pengembangan aspek bahasa ekspresif agar anak mampu berkomunikasi secara aktif dengan lingkungan dan mengembangkan minat anak untuk mengajukan pertanyaan-pertanyaan kepada teman sebaya maupun orang dewasa. Namun fakta di lapangan menunjukkan bahwa pengembangan kemampuan bahasa ekspresif anak belum maksimal. Kurangnya kemampuan anak berbahasa ekspresif disebabkan oleh beberapa hal, salah satunya kegiatan pembelajaran yang kurang memperhatikan karakteristik anak usia dini. Observasi di TK PGRI 1 Wagir menunjukkan kemampaun bahasa ekspresif anak 
masih rendah, anak masih malu dan merasa takut untuk mengajukan pertanyaan maupun menjawab pertanyaan. Hal tersebut dikarenakan kegiatan pembelajaran yang dilakukan berpuasat pada guru (Teacher center) artinya anak hanya mendengarkan penjelasan dari guru tentang kegiatan hari ini dan selanjutnya mengerjakan penugasan berupa LKS dan majalah tematik bulanan. Teknik Teacher center ini menyebabkan kurangnya perbendaharaan kata, kemampuan menyampaikan gagasan, serta kemampuan menceritakan kegiatan atau pengalaman bermain pada hari itu tidak berkembang dengan baik. Pendekatan pembelajaran yang tepat dapat mendorong anak untuk bereksplorasi dengan bahasanya, bertanya dan menjawab pertanyaan.

Penerapan pembelajaran saintifik pada anak usia dini mengubah paradigma dari teacher center menjadi student center. Anak tidak lagi dianggap sebagai tokoh pasif yang hanya melakukan apa yang diperintahkan oleh gurunya, dimana anak tidak diberikan kesempatan untuk menuangkan ide dan gagasan mereka serta berinteraksi dengan lingkungannya. Pendekatan saintifik merupakan salah satu upaya untuk memecahkan masalah pada anak usia dini (Widiastuti, Tegeh, \& Ujianti 2018). Dalam pendekatan saintifik ini mengembangkan empat kompetensi inti yang tertulis dalam Kurikulum PAUD 2013. Kompetensi tersebut, meliputi ranah sikap, ranah pengetahuan, dan ranah keterampilan. Pendekatan saintifik pada anak usia dini tidak dilakukan seperti proses pembelajaran sains, namun proses sains tersebut yang digunakan dalam kegiatan pembelajaran (Suastiningsih,dkk 2017).

Ada beberapa prinsip pembelajaran dengan pendekatan saintifik menurut Haenilah (2015), yaitu (1) pembelajaran melibatkan anak secara aktif dan berpusat pada anak; (2) pembelajaran yang dilakukan dapat menanamkan konsep pada diri anak; (3) pembelajaran mendorong anak untuk menemukan hal baru secara mandiri; (4) pembelajaran yang ramah anak; (5) memberikan kesempatan pada anak untuk mengekspresikan segala pengalaman belajarnya; (6) mendorong kemampuan berpikir tingkat tinggi; (7) menyenangkan dan mempunyai nilai sosial.

Penelitian Yusri (2015) tentang keterkaitan scientific learning dengan kemampuan berpikir kritis menunjukkan pengaruh terhadap kemampuan berbahasa anak. Penelitian yang dilakukan oleh Mahendra, Arini, \& Sumantri (2016) tentang pengaruh pendekatan saintifik terhadap keterampilan berbicara anak juga menunjukkan pengaruh yang signifikan. Selanjutnya Suryana (2017) meneliti keterkaitan pembelajaran tematik terpadu dengan pendekatan saintifik sebagai bentuk discovery learning. Penelitian kualitatif oleh Puspita (2016) menggambarkan peningkatan kemampuan berbicara anak dengan diterapkan pendekatan saintifik dengan media kartu gambar.

Berdasarkan penelitian yang relevan di atas menjadi dasar kuat untuk memunculkan ide baru dalam penelitian ini. Perbedaan penelitian ini dengan penelitian sebelumnya terletak pada media yang digunakan. Pada penelitian terdahulu, peneliti dalam melaksanakan pendekatan saintifik selalu membuat dan menentukan media pembelajaran, sedangkan dalam penelitian ini tidak harus menggunakan media pembelajaran yang ditentukan terlebih dahulu. Artinya, pendekatan saintifik dalam kegiatan pembelajaran dapat dilakukan, meskipun tanpa media dengan tetap memperhatikan kebutuhan anak, yaitu belajar dan bermain secara menyenangkan.

\section{METODE}

Penelitian ini adalah jenis penelitian quasy experimen dengan pendekatan kuantitatif. Menurut Sugiyono (2011) metode penelitian kuantitatif digunakan untuk mengetahui atau menguji hipotesis atau dugaan awal melalui pengumpulan data berupa angka dengan menggunakan analisis data statistik. Terdapat dua variabel yang digunakan dalam penelitian ini. Variabel pertama adalah variabel independen atau variabel bebas yang berupa penerapan pendekatan saintifik, sedangkan variabel dependen atau variabel terikat dalam penelitian ini adalah aspek bahasa ekspresif. Variabel independen menjadi berpengaruh terhadap berubahnya variabel dependen (Sugiyono, 2011).

Sampel penelitian adalah kelas B1 sebanyak 15 anak didik dan merupakan kelas eksperimen, sedangkan kelas B2 sebanyak 15 anak didik sebagai kelas kontrol. Cara menentukan kelompok dipilih dengan teknik purpose sampling. Teknik ini pada umumnya digunakan untuk sampel yang kecil kurang dari 30, agar menghasilkan keputusan yang akurat. Pengumpulan data menggunakan teknik observasi, wawancara, dan dokumentasi.

Instrumen penelitian berupa lembar observasi yang sudah diuji validitas dan reliabilitasnya. Teknik analisis data menggunakan uji paired t sampel karena untuk mengetahui pengaruh dari kedua variabel. Sebelum uji hipotesis, dilakukan uji prasyarat normalitas dan homogenitas data dengan bantuan SPSS 19.

\section{HASIL}

Berdasarkan analisis data posttest dari kelompok eksperimen dan kelompok kontrol diperoleh deskripsi tingkat kemampuan aspek bahasa ekspresif anak sebagaimana ditunjukkan pada tabel 1.

Tabel 1. Data Postest Kelas Kontrol

\begin{tabular}{ccc}
\hline Kategori & Frekuensi & Persentase \\
\hline BB & 1 & $6.67 \%$ \\
MB & 13 & $86.67 \%$ \\
BSH & 1 & $6.67 \%$ \\
BSB & 0 & $0.00 \%$ \\
\hline
\end{tabular}


Data nilai sesudah perlakuan pembelajaran dengan pendekatan saintifik terhadap kemampuan bahasa ekspresif anak pada kelompok kontrol dengan rincian 13 anak dengan persentase $86.67 \%$, satu anak dengan persentase $6.67 \%$ dan satu anak dengan persentase $6.67 \%$ dari total keseluruhan 15 anak.

Tabel 2. Data Postest Kelas Eksperimen

\begin{tabular}{ccc}
\hline Kategori & Frekuensi & Persentase \\
\hline BB & 0 & $0.00 \%$ \\
MB & 0 & $0.00 \%$ \\
BSH & 3 & $20.00 \%$ \\
BSB & 12 & $80.00 \%$
\end{tabular}

Data nilai sesudah perlakuan pembelajaran dengan pendekatan saintifik terhadap kemampuan bahasa ekspresif anak pada kelompok eksperimen. Hasil postest menunjukkan 12 anak mengalami perkembangan dengan sangat baik serta mendapat nilai persesntase $80 \%$. Selanjutnya, tiga anak mendapat persentase $20 \%$ dengan keterangan mengalami perkembangan sesuai dengan harapan. Jumlah keseluruhan kelompok eksperimen adalah 15 anak didik.

Tabel 3. Hasil Penghitungan Uji Paired t Sampel

\begin{tabular}{lcccccc}
\hline Kelompok & Mean & Std. Deviation & Std Error Mean & t & df & Sig. \\
\hline Eksperimen & -27.26667 & 3.73146 & .96346 & -28.301 & 14 & .000 \\
Kontrol & -2.13333 & 4.34029 & 1.12066 & -1.904 & 14 & .078 \\
\hline
\end{tabular}

Data uji paired $\mathrm{t}$ sampel diperoleh $\mathrm{t}$ hitung sebesar 28.301 dengan nilai signifikasi 0.000. Dengan demikian, dapat disimpulkan terdapat pengaruh pendekatan saintifik terhadap kemampuan bahasa ekspresif anak kelompok B TK PGRI 1 Wagir.

\section{PEMBAHASAN}

Penelitian ini bertujuan untuk mengetahui pengaruh pendekatan saintifik terhadap kemampuan aspek bahasa ekspresif anak kelompok B di TK PGRI 1 Wagir. Berdasarkan hasil analisis data anak didik yang kegiatan pembelajarannya diterapkan pendekatan saintifik mempunyai kemampuan berbahasa ekspresif lebih baik dibandingkan dengan anak didik yang kegiatan pembelajarannya konvensional. Data uji t menunjukkan t table 28.301 dengan nilai signifikasi lebih kecil dari nilai signifikasi 0.005, artinya terdapat pengaruh pendekatan saintifik terhadap kemampuan aspek bahasa ekspresif anak didik.

Tahapan penelitian terdiri dari dua tahap yaitu tahap persiapan dengan mengumpulkan data-data penelitian dan tahap pelaksanaan penelitian. Data yang sudah terkumpul dijadikan bekal untuk melaksanakan proses penelitian. Kelas eksperimen pada penelitian ini diberikan treatment berupa pendekatan saintifik dalam pembelajaran. Pendekatan tersebut dilakukan dengan cara mengamati,menanya,mengumpulkan informasi, menalar dan mengkomunikasikan. Pada kelas kontrol tidak diberikan perlakuan berupa pendekatan saintifik. Pembelajaran dilakukan seperti biasanya, yaitu dengan metode ceramah dan pemberian tugas mengerjakan perintah di majalah bulanan.

Penerapan pendekatan saintifik dilakukan guru pada setiap kegiatan main. Penerapan itu dapat pada kegiatan pembukaan, kegiatan inti, maupun kegiatan penutup. Model pembelajarannya pun tidak harus model sentra, karena setiap model pembelajaran bisa di terapkan dengan kombinasi pendekatan saintifik. Tujuan dari pendekatan saintifik adalah agar anak terbiasa berpikir kritis sejak usia dini (Widiastuti et al., 2018). Kemampuan-kemampuan anak dalam mengidentifikasi suatu benda, menganalisis data, membuat estimasi, kemampuan menalar menjadi bekal penting ketika anak-anak sudah menghadapi kehidupan yang sebenarnya. Hal ini sejalan dengan pendapat Rohita, Fitria, Bustan, \& Haryadi (2018) penerapan dan pemahaman pendekatan saintifik dalam kurikulum 2013 dilakukan dengan lima tahapan secara umum.

Pembelajaran bermakna didapatkan anak melalui kegiatan yang menyenangkan. Kegiatan tersebut bisa dilakukan guru dengan mengajak anak bermain karena melalui bermain, seorang anak belajar memperluas gagasan-gagasan dengan cara bertanya pada guru. Kegiatan bertanya yang dilakukan oleh anak menunjukkan bahwa dalam pendekatan saintifik terdapat tahapan menanya yang dapat mengembangkan aspek perkembangan lainnya selain bahasa, yaitu aspek nilai-nilai rasa syukur atas ciptaan Tuhan (Slamet \& Kurniati, 2018). Sejalan dengan hal itu (Widowati, Nurohman, \& Anjarsari, 2017) memaparkan sikap ilmiah siswa dapat dikembangkan dengan pembelajaran sains otentik.

Anak-anak menggunakan panca inderanya untuk mengidentifikasi suatu benda. Dalam kegiatan mengamati tersebut terjadi proses pemahaman benda secara konkrit berdasarkan warna dan ukuran. Selain melakukan pengamatan, anak-anak juga asyik menghitung benda dan mengklasifikasikannnya ke dalam kelompok yang sama. Proses tanya jawab juga terjadi antara anak dengan temannya. Seperti pendapat (Putri, Rakimahwati, \& Zulminiati, 2018) bermain menjadi salah satu alternatif untuk mengembangkan bahasa lisan anak. Anak senang belajar dan bermain dengan benda konkret. Benda dan bahan belajar yang disediakan guru menjadi media bagi anak untuk mengekspresikan rasa ingin tahunya. Proses belajar secara konkret akan menanamkan konsep yang kuat pada pikiran anak. Sebagaimana teori schemata yang menjelaskan bahwa anak usia dini belajar dari apa yang dilihat. Anak terlihat asyik menggali pengetahuan dengan bercakap-cakap antar sesama teman dan melalui benda 
yang dipegang anak. Dengan berbuat anak dapat merasakan dan menemukan pengetahuan baru yang bermakna. Anak melakukan kegiatan dengan dengan menggunakan semua panca inderanya.

Anak usia dini belajar dengan mencoba dan menyelidiki. Dalam hal ini guru perlu menyediakan bahan bermain dan media pembelajaran yang cukup untuk mendukung kegiatan anak. Kegiatan bermain dan belajar yang menyenangkan dapat menyambungkan sinaps-sinaps di otak anak. Semakin tersambung sinaps tersebut, maka akan semakin banyak pula pengetahuan baru yang didapat oleh anak. Sebagai guru tentunya dituntut utuk menciptkan suasana dan kegiatan bermain yang menyenangkan karena menurut Rosalina (2011) kegiatan bermain yang menyenangkan dapat meningkatkan kemampuan berbahasa anak, tidak dalam kondisi tertekan maupun pemaksaan. Munastiwi (2015) berpendapat kecerdasan dari berbagai aspek kecerdasan termasuk aspek bahasa dapat dioptimalkan dengan pendekatan pembelajaran saintifik. Selain itu, kreativitas anak juga dapat berkembang dengan baik melalui kegiatan-kegiatan ilmiah.

Keaktifan seorang anak dalam kegiatan pembelajaran menjadi tanda bahwa penerapan pendekatan saintifik sudah berhasil. Kegiatan pembelajaran yang disajikan guru tidak terbatas pada kegiatan sains, tetapi dalam kegiatan main keaksaraan, main balok, main pembangunan, dan main peran juga menekankan pada peningkatan aspek bahasa anak. Sejalan dengan Ayuningtiyas (2013) keterampilan berbahasa dan berbicara pada anak dapat dikembangkan melalui kegiatan bermain peran. Kegiatan pembelajaran yang dilakukan dengan tahapan saintifik akan membiasakan anak bersikap ilmiah dan belajar mengambil keputusan dengan tepat. Pendapat (Gultom, 2017) pendekatan saintifik memberikan kesempatan kepada anak didik untuk melaporkan temuan baru melalui bahasa berdasarkan fakta yang sesuai dengan kompetensi inti.

Penelitian ini sejalan dengan Mastiah \& Ason (2016) yang meneliti pemahaman bahasa dan lingkungan anak melalui penelitian eksperimen dan diperoleh perbedaan yang signifikan dengan diterapkan pendekatan saintifik dalam pembelajaran. Penelitian serupa oleh Utami (2016) tentang keberhasilan penerapan pendekatan saintifik dalam meningkatkan beberapa kompetensi inti pada anak. Sebagaimana Marwiyanti (2017) melalui penelitian kualitatif memaparkan peranan pendekatan saintifik dalam memancing kreativitas anak, sehingga meningkatkan rasa percaya diri anak untuk berkomunikasi dan memecahkan masalah. Oleh karena itu, penelitian-penelitian di atas dijadikan dasar kuat untuk melakukan penelitian tentang pengaruh pendekatan saintifik terhadap kemampuan berbahasa ekspresif anak didik.

\section{SIMPULAN}

Berdasarkan hasil penelitian disimpulkan bahwa terdapat pengaruh yang signifikan kemampuan berbahasa ekspresif anak dengan penerapan pendekatan saintifik. Hasil analisis data menunjukkan anak yang kegiatan pembelajarannya diterapkan pendekatan saintifik mempunyai kemampuan berbahasa ekspresif lebih baik dibandingkan dengan anak didik yang kegiatan pembelajarannya hanya dengan majalah. Data uji t menunjukkan t table 28.301 dengan nilai signifikasi lebih kecil dari nilai signifikasi 0.005, artinya terdapat pengaruh pendekatan saintifik terhadap kemampuan aspek bahasa ekspresif anak didik.

Dalam mengembangkan aspek bahasa ekspresif, pendekatan saintifik sudah terbukti mempunyai pengaruh. Untuk itu pendekatan saintifik perlu diterapkan kembali dalam penelitian untuk mengembangkan aspek-aspek yang lain. Jadi tidak terbatas pada aspek bahasa ekspresif. Bagi guru TK, penerapan pendekatan saintifik dalam pembelajaran dapat dijadikan sebagai salah satu metode untuk mengembangkan aspek bahasa ekspresif.

\section{DAFTAR RUJUKAN}

Ayuningtiyas, V. (2013). Metode Bermain Peran (Role Playing) Dalam Upaya Menumbuhkembangkan Keterampilan Berbicara Bahasa Indonesia pada Anak Usia Dini di TK Bhayangkari 17 Cimahi. Empowerment, 2(2252-4738). https://doi.org/10.1017/CBO9781107415324.004

Dhieni, N. (2013). Metode Pengembangan Bahasa. Jakarta: Universitas Terbuka.

Gultom, E. L. (2017). Penerapan Pendekatan Saintifik pada Pembelajaran untuk Penanaman Kompetensi Inti. Prosiding Seminar Nasional Tahunan Fakultas Ilmu Sosial Universitas Negeri Medan Tahun, 1(1), 365-370.

Haenilah, E. . (2015). Kurikulum dan Pembelajaran PAUD. Yogyakarta: Media Akademi.

Inten, D. N. (2017). Pengembangan Keterampilan Berkomunikasi Anak Usia Dini melalui Metode Bermain Peran. IO(1), 109_ 120.

Jafar, F. S., \& Satriana, M. (2018). Penerapan Model Pembelajaran Sentra Dalam Pengembangan Kecerdasan Bahasa Ekspresif Anak Usia Dini. Jurnal Psikologi, 4(1), 190-214.

Madyawati, L. (2016). Strategi Pengembangan Bahasa Anak. Jakarta: Kencana.

Mahendra, K. A., Arini, N. W., \& Sumantri, M. (2016). Pengaruh Penerapan Pendekatan Saintifik Berbantuan Media Gambar Berseri Terhadap Keterampilan Berbicara Siswa Kelas IV SDN 1 Sangsit. PGSD Universitas Pendidikan Ganesha, 3(1).

Marwiyanti, S. (2017). Pembelajaran Saintifik pada Anak Usia Dini Dalam Pengembangan Kreativitas di TK Negeri Pembina Kota Salatiga. UIN Sunan Kalijaga Yogyakarta.

Mastiah., \& Ason. (2016). Penerapan Pendekatan Saintifik pada Pendidikan Anak Usia Dini (PAUD) di Kabupaten Melawi. Jurnal Pendidikan Dasar, 4(2), 155-168.

Munastiwi, E. (2015). Implementasi Pendekatan Santifik pada Pendidikan Anak Usia Dini. Pendidikan Anak, 1(2), $43-50$. https://doi.org/10.14421/jaa.2015.12.43-50 
Putri, M., Rakimahwati, R., \& Zulminiati, Z. (2018). Efektivitas Penerapan Metode Bermain Peran Makro terhadap Perkembangan Bahasa Lisan Anak di Taman Kanak-kanak Darul Falah Kota Padang. Journal of Studies in Early Childhood Education (J-SECE), 1(2), 80. https://doi.org/10.31331/sece.v1i2.730

Rohita, R., Fitria, N., Bustan, R., \& Haryadi, D. (2018). Teacher's Understanding of the Scientific Approach in the 2013 Curriculum for Early Childhood Education. Jurnal Obsesi : Jurnal Pendidikan Anak Usia Dini, 2(2), 235. https://doi.org/10.31004/obsesi.v2i2.105

Rosalina, A. (2011). Peningkatan Kemampuan Bahasa Anak Usia Dini melalui Kegiatan Bermain. Psycho Idea, (ISSN 16931076), 19-35.

Santrock, J. W. (2011). Masa Perkembangan Anak. Jakarta: Salemba Humanika.

Slamet, A., \& Kurniati, A. (2018). Scientific Approach in Imparting Islamic Values In Early Childhood : A Case Study in Raudatul Aisyiyah Athfal Baubau. Al-Ta'lim Journal, 25(1), 71-76.

Suastiningsih, D. (2017). Anak Kelompok B Jurusan Pendidikan Guru Pendidikan Anak Usia Dini Fakultas Ilmu Pendidikan Universitas Pendidikan Ganesha Abstrak e-Journal Pendidikan Anak Usia Dini Universitas Pendidikan Ganesha. Pendidikan Anak Usia Dini Universitas Pendidikan Ganesha, 4(3).

Sugiyono. (2011). Metode Penelitian Kuantitatif Kualitatif dan R\&D. Bandung: Alfabeta.

Suryana, D. (2017). Pembelajaran Tematik Terpadu Berbasis Pendikatan Saitifik di Taman Kanak-Kanak. Jurnal Pendidikan Usia Dini, 11(1), 67-82.

Utami, T. (2016). Penanaman Kompetensi Inti Anak Usia Dini. UIN Sunan Kalijaga Yogyakarta.

Widiastuti, E., Tegeh, M., \& Ujianti, P. R. (2018). Pemecahan Masalah pada Anak Kelompok B di Taman Kanak-Kanak Jurusan Teknologi Pendidikan Fakultas Ilmu Pendidikan Universitas Pendidikan Ganesha E-Journal Pendidikan Anak Usia Dini Universitas Pendidikan Ganesha. Pendidikan Anak Usia Dini Universitas Pendidikan Ganesha, 6(2).

Widowati, A., Nurohman, S., \& Anjarsari, P. (2017). Developing Science Learning Material with Authentic Inquiry Learning Approach to Improve Problem Solving and Scientific Attitude. Jurnal Pendidikan IPA Indonesia, 6(1), 32-40. https://doi.org/10.15294/jpii.v6i1.4851

Yusri, N. (2015). Keterkaitan Scientific Learning dengan Kemampuan Berpikir Kritis (Kajian Proses Pembelajaran di Sekolah Dasar Budi Mulia Dua Sedayu Bantul). Tesis tidak diterbitkan. UIN Sunan Kalijaga Yogyakarta, Yogyakarta. 